\title{
Overexpression of the Apple MpNPR1 Gene Confers Increased Disease Resistance in Malus $\times$ domestica
}

\author{
M. Malnoy, ${ }^{1}$ Q. Jin, ${ }^{2}$ E. E. Borejsza-Wysocka, ${ }^{1}$ S. Y. He ${ }^{2}$ and H. S. Aldwinckle ${ }^{1}$ \\ ${ }^{1}$ Department of Plant Pathology, Cornell University, Geneva, NY 14456 U.S.A.; ${ }^{2}$ DOE Plant Research Lab and Department \\ of Plant Biology, Michigan State University, East Lansing, MI 48824, U.S.A.
}

Submitted 21 February 2007. Accepted 22 July 2007.

\begin{abstract}
The NPR1 gene plays a pivotal role in systemic acquired resistance in plants. Its overexpression in Arabidopsis and rice results in increased disease resistance and elevated expression of pathogenesis-related $(P R)$ genes. An NPR1 homolog, $M p N P R 1-1$, was cloned from apple (Malus $\times$ domestica) and overexpressed in two important apple cultivars, Galaxy and M26. Apple leaf pieces were transformed with the MpNPRI cDNA under the control of the inducible Pin2 or constitutive Cauliflower mosaic virus (CaMV)35S promoter using Agrobacterium tumefaciens. Overexpression of MpNPR1 mRNA was shown by reverse transcriptase-polymerase chain reaction. Activation of some $P R$ genes $(P R 2, P R 5$, and $P R 8)$ was observed. Resistance to fire blight was evaluated in a growth chamber by inoculation of the shoot tips of our own rooted 30-cm-tall plants with virulent strain Ea273 of Erwinia amylovora. Transformed Galaxy lines overexpressing MpNPRI had 32 to $40 \%$ of shoot length infected, compared with $80 \%$ in control Galaxy plants. Transformed M26 lines overexpressing MpNPR1 under the control of the CaMV35S promoter also showed a significant reduction of disease compared with control M26 plants. Some MpNPR-overexpressing Galaxy lines also exhibited increased resistance to two important fungal pathogens of apple, Venturia inaequalis and Gymnosporangium juniperi-virginianae. Selected transformed lines have been propagated for field trials for disease resistance and fruit quality.
\end{abstract}

Plants have evolved sophisticated detection and response systems that decipher pathogen signals and induce appropriate defenses. Upon pathogen detection, plants activate a number of early responses that lead to the production of a broad spectrum of defense molecules (Chisholm et al. 2006; Takken and Joosten 2000). In many cases, products of host resistance $(R)$ genes mediate pathogen recognition and activate pathways that are involved in local defenses, such as the hypersensitive response (HR) and the oxidative burst (Greengerq and Yao 2004; Hammond-Kosack and Jones 1996). These induced defenses are often expressed not just locally but also systemically, thereby protecting the plant from subsequent pathogen attacks. One of the best-understood responses is systemic acquired resistance (SAR) (Durrant and Dong 2004; Ryals et al. 1996; Sticher et al. 1997). Salicylic acid (SA) is an essential signal in

M. Malnoy and Q. Jin made equal contributions to this work.

Corresponding author: H. S. Aldwinckle; E-mail: hsa1@ cornell.edu; Telephone: +1 001315787 2369; Fax: +1 0013157872389 .

Current adress for M. Malnoy: IASMA Research Centre, Via E. Mach 1, 38010 San Michele all'Adige (TN), Italy. the induction of SAR (Dempsey et al. 1999; Gaffney et al. 1993; Métraux et al. 1990). In addition, exogenous application of SA or its analogs, such as benzo(1,2,3)thiadiazole-7-carbothioic acid (BTH) and 2,6-dichlorosinonicotinic acid (INA), triggers SAR (Friedrich et al. 2001; Gorlach et al. 1996; Métraux et al. 1990; Morris et al. 1998). Along with an increase of SA levels, increased expression of pathogenesisrelated $(P R)$ genes has also been tightly correlated with the onset of SAR. Only a few $P R$ genes have been shown to have antimicrobial activity in vitro or to confer increased resistance when overexpressed in plants (Morrisey et al. 1999; Smith 1996), and no single $P R$ gene has been shown to be essential for SAR, suggesting that the coordinated expression of these genes and other defense responses is needed to produce resistance.

Genetic analysis of plant mutants impaired in mounting a resistance response to invading pathogens have uncovered a number of distinct but interconnecting signal networks that are under both positive and negative control. In one such screen, the Arabidopsis thaliana gene NPRI (for nonexpressor of PR, also called NIMI for nonimmunity or $S A L 1$ for salicylic acidinsensitivity; hereinafter called AtNPRI) was identified as a key factor in transducing the signal leading to SAR (Cao et al. 1994; Delaney et al. 1995; Ryals et al. 1996; Shah et al. 1997). In addition, this gene also participates in induced systemic resistance (ISR) that is activated upon colonization of selected strains of nonpathogenic rhizobacteria around roots (Pieterse et al. 1998; Spoel et al. 2003). AtNPRl encodes a protein that contains a BTB/BOZ domain and an ankyrin repeat domain (Cao et al. 1997; Ryals et al. 1997). Both domains are known to mediate protein-protein interactions and are present in proteins with diverse functions (Aravind and Koonin 1999), including the transcriptional regulator $\mathrm{I}_{\mathrm{k}} \mathrm{B}$, which mediates innate immune responses in animals (Baldwin 1996). Upon induction of SAR, AtNPR1 is apparently translocated to the nucleus (Kinkeman et al. 2000; Somssich 2003), in which it interacts with the TGA family of basic leucine zipper (bZIP) transcription factors (Després et al. 2000; Fan and Dong 2002; Kim and Delaney 2002; Subramanian et al. 2001; Zhang et al. 1999; Zhou et al. 2000) that are involved in the SA-dependent activation of $P R$ genes (Niggweg et al. 2000).

Overexpression of AtNPR1 in A. thaliana, rice, tomato, and wheat has been demonstrated to induce enhanced fungal and bacterial resistance (Cao et al 1998; Chern et al. 2001, 2005; Fitzgerald et al. 2004; Friedrich et al. 2001; Lin et al. 2004; Makandar et al. 2006). In A. thaliana, overexpression of AtNPRI and enhanced resistance are correlated with both enhanced and quicker $P R$ gene expression, suggesting that NPRI induces enhanced resistance through elevated expression of $P R$ genes (Cao et al. 1998; Friedrich et al. 2001). Thus, 
we decided to employ the NPRI overexpression strategy to generate apple plants with a broad-spectrum disease resistance, in particular to the devastating fire blight disease caused by Erwinia amylovora (Burr.).

Most modern apple (Malus $\times$ domestica) cultivars are susceptible to E. amylovora and apple scab caused by the asco- mycete fungus Venturia inaequalis (Cooke). Fire blight is the major bacterial disease of Maloideae (pear, apple, quince) and several other members of the Rosaceae. After entering the plants through natural openings or wounds, the bacteria spread quickly along the stems to the main branches, producing the characteristic symptom of this disease: a necrotic shoot blight

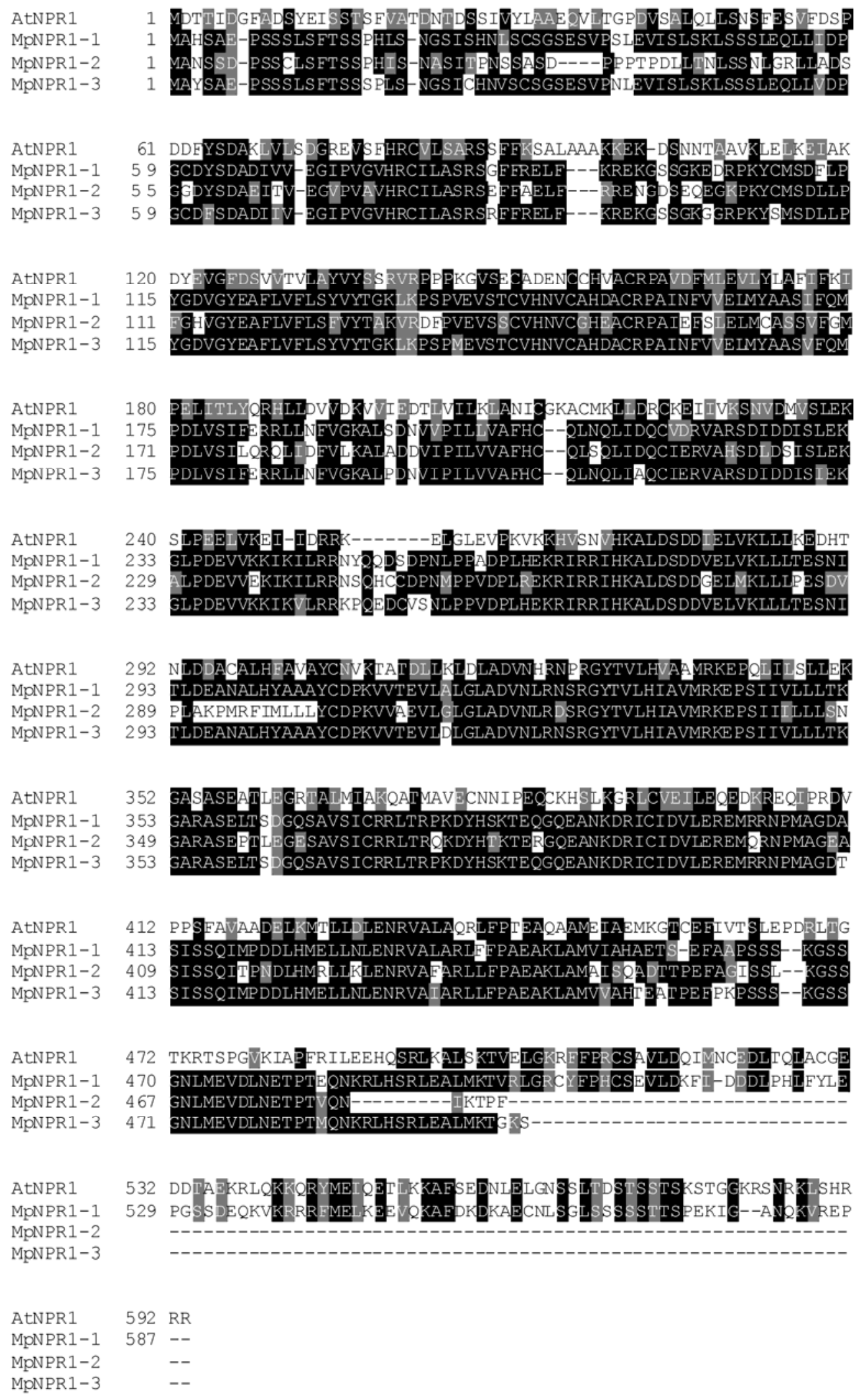

Fig. 1. Alignment of the deduced amino acid sequences of MpNPR1-1, MpNPR1-2, and MPNPR1-3 to that of the Arabidopsis thaliana AtNPR1 gene. 
that can kill a tree in one season (Thomson 2000). Here, we report that overexpression of the Malus NPR1 (MpNPR1 hereinafter) gene in two apple cultivars, Galaxy and M26, confers increased resistance to a bacterial and two fungal pathogens.

\section{RESULTS}

Cloning and characterization of the apple MpNPR1 gene.

To clone the ortholog of the AtNPRl gene from apple, we screened an apple cDNA library using AtNPRl as a probe. Three clones were obtained and designated MpNPR1-1, MpNPR1-2, and MpNPR1-3. MpNPR1-1 shares 80\% identity with MpNPRI-2 and 85\% identity with MpNPRI-3 at the nucleotide level. The deduced amino-acid sequences of the three genes share about $35 \%$ identity with that of the AtNPR 1 protein (Fig. 1). The most conserved region corresponds to the ankyrin repeats, a protein-protein interaction domain that is a signature of the AtNPR1 protein.

The AtNPRl gene was previously shown to be inducible by treatment with the SAR inducer BTH (Cao et al. 1998). To further examine the relatedness of the three putative apple NPRI genes to Arabidopsis NPR1, Northern blot analysis using gene-specific probes ( $5^{\prime}$ noncoding regions) was conducted. Only MpNPR1-1 was found to be induced by BTH (Fig. 2), suggesting that MpNPR1-1 but not MpNPR1-2 or MpNPR1-3 is a likely ortholog of the AtNPRl gene. In support of this

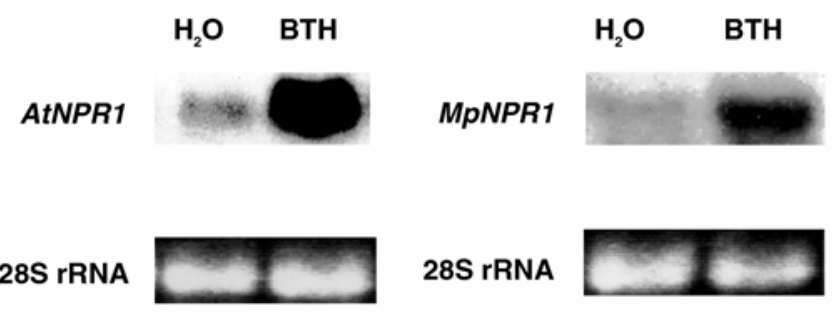

Fig. 2. Northern blot analysis of expression of AtNPR1 and MpNPR1-1 genes by benzo(1,2,3)thiadiazole-7-carbothioic acid (BTH). Left, Expression of AtNPR1 in Arabidopsis thaliana treated with $\mathrm{H}_{2} \mathrm{O}$ and BTH 3 days prior to the harvest of leaves. Right, Expression of MPNPR1-1 in apple seedlings treated with $\mathrm{H}_{2} \mathrm{O}$ and BTH. The 5' noncoding regions of AtNPRI and MPNPR1-1 were used as probes. notion, phylogenetic tree analysis was conducted, which showed that MpNPR1-1 was most closely related to AtNPRI (Fig. 3). Therefore, $M p N P R 1-1$ was chosen for further experiments and referred to as $M P N P R 1$.

\section{Transformation efficiency and ploidy level.}

We conducted apple transformation with A. tumefaciens EHA105 pCH32 containing binary vector pKYLX35SAtNPR1, pKYLX35SMpNPR1, or pKYLXPINMpNPR1. A total of 50 leaves taken from Galaxy and M.26 were transformed for each construct. We obtained 5, 12 and 9 transformed Galaxy lines, and 19, 5, and 20 transformed M.26 lines for pKYLXAtNPR1, pKYLX35SMpNPR1, or pKYLXPINMpNPR1, respectively. The efficiency of transformation (10 to $24 \%$ for Galaxy and 10 to $40 \%$ for M.26) was higher than that obtained with other Malus $\times$ domestica genotypes (Faize et al. 2003, 2004; Puite and Schaart 1996; Szankowski et al 2003) or other Rosaceae woody plants (Reynoird et al. 1999; Scorza et al. 1994). Presence of the NPRl genes was verified by polymerase chain reaction (PCR) analysis of transformed lines growing on selective medium. Ploidy level determined by flow cytometry showed that all of the transformed lines were diploid, like the nontransformed Galaxy and M.26.

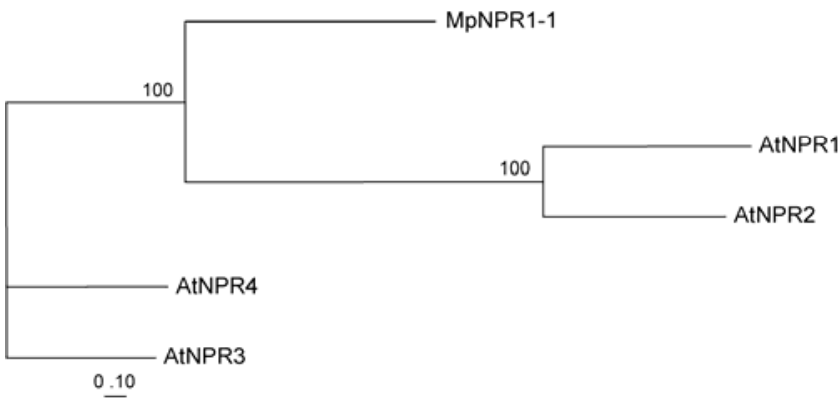

Fig. 3. Phylogenetic tree generated by parsimony analysis based on shared amino acids of MpNPR1-1, AtNPR1 (AT1G64280), AtNPR2 (AT4G26120), AtNPR3 (AT5G45110), and AtNPR4 (AT4G19660). The scale is the expected number of substitutions per position. Numbers at the nodes are presented only for percentage bootstrap values above $50 \%$ of 1,000 resamplings.

Table 1. Evaluation of fire blight resistance in our own rooted plants compared with grafted Galaxy plants containing PINMpNPR1, 35SAtNPR1, and $35 \mathrm{SMpNPR} 1^{\mathrm{a}}$

\begin{tabular}{|c|c|c|c|c|c|}
\hline Lines & Constructs & Rooted plants $(\%)^{b}$ & Waller group & Grafted plants $(\%)^{\mathrm{c}}$ & Waller group \\
\hline Galaxy & & 83.0 & A & 78.9 & A \\
\hline TGx-1508 & 35SMpNPR1 & 65.9 & $\mathrm{AB}$ & $\ldots$ & $\ldots$ \\
\hline TGx-1517 & 35SAtNPR1 & 65.0 & $\mathrm{AB}$ & $\ldots$ & $\ldots$ \\
\hline TGx-1515 & 35SMpNPR1 & 61.6 & $\mathrm{AB}$ & $\ldots$ & $\ldots$ \\
\hline TGx-1510 & 35SMpNPR1 & 55.6 & $\mathrm{BC}$ & $\ldots$ & $\ldots$ \\
\hline TGx-1524 & 35SMpNPR1 & 55.5 & $\mathrm{BC}$ & $\ldots$ & $\ldots$ \\
\hline TGx-1522 & 35SMpNPR1 & 55.4 & $\mathrm{BC}$ & $\ldots$ & $\ldots$ \\
\hline TGx-1511 & 35SMpNPR1 & 53.0 & $\mathrm{BCD}$ & $\ldots$ & $\ldots$ \\
\hline TGx-1320 & PINMpNPR1 & 52.9 & $\mathrm{BCD}$ & $\ldots$ & $\ldots$ \\
\hline TGx-1518 & 35SAtNPR1 & 48.0 & BCDE & $\ldots$ & $\ldots$ \\
\hline TGx-1491 & PINMpNPR1 & 47.3 & BCDE & 49.2 & B \\
\hline TGx-1321 & PINMpNPR1 & 46.9 & BCDE & 49.0 & B \\
\hline TGx-1521 & 35SMpNPR1 & 45.4 & BCDEFG & $\ldots$ & $\ldots$ \\
\hline TGx-1322 & PINMpNPR1 & 40.3 & CDEF & 37.5 & $\mathrm{C}$ \\
\hline TGx-1323 & PINMpNPR1 & 35.0 & CDEFG & 35.0 & $\mathrm{C}$ \\
\hline TGx-1319 & PINMpNPR1 & 31.0 & EFGH & 34.0 & $\mathrm{C}$ \\
\hline TGx-1509 & PINMpNPR1 & 28.9 & FGH & $\ldots$ & $\ldots$ \\
\hline M.7 & $\ldots$ & 22.3 & FGH & 17.0 & D \\
\hline TGx-1520 & 35SMpNPR1 & 17.2 & GH & $\ldots$ & $\ldots$ \\
\hline TGx-1523 & 35SMpNPR1 & 10.6 & $\mathrm{H}$ & $\ldots$ & $\ldots$ \\
\hline
\end{tabular}

\footnotetext{
${ }^{a}$ By shoot inoculation with Erwinia amylovora Ea 273 at $5 \times 10^{7} \mathrm{CFU} \mathrm{ml}{ }^{-1}$.

$\mathrm{b}$ The percentage of shoot length infected in our own rooted plants in a growth chamber.

${ }^{c}$ The percentage of shoot length infected in grafted plants in the greenhouse.
} 
Southern blot analysis of seven selected transformed Galaxy lines containing the PINMpNPR1 insert showed that the tested transformed lines all contained a single copy of the transferred gene in their genome (data not shown).

\section{Susceptibility of transformed lines to fire blight.}

To characterize the response of the transformed lines to fire blight, 10 to 20 acclimated plants per line were inoculated with E. amylovora Ea 273 at $5 \times 10^{6} \mathrm{CFU} \mathrm{m}^{-1}$ for $\mathrm{M} .26$ or $5 \times 10^{7}$ $\mathrm{CFU} \mathrm{m} \mathrm{m}^{-1}$ for Galaxy in two to three independent experiments. The responses were similar in the replicated experiments, as indicated by the low confidence intervals of the means. Three weeks after inoculation, $83 \%$ of the shoot length infected in nontransformed Galaxy showed necrosis, whereas $22 \%$ of the shoot length in M.7 (resistant control) was necrotic (Table 1). By contrast, all of the transformed Galaxy lines expressing the Malus $\times$ domestica or A. thaliana NPRl gene under the con-

Table 2. Fire blight resistance in our own rooted M.26 plants ${ }^{\mathrm{a}}$

\begin{tabular}{|c|c|c|c|}
\hline Lines & Constructs & $\begin{array}{l}\text { Shoot length } \\
\text { infected }(\%)\end{array}$ & Waller group \\
\hline T26-1304 & PINMpNPR1 & 100 & A \\
\hline T26-1309 & PINMpNPR1 & 97.6 & $\mathrm{AB}$ \\
\hline T26-1306 & PINMpNPR1 & 97.1 & $\mathrm{ABC}$ \\
\hline T26-1297 & PINMpNPR1 & 95.8 & $\mathrm{ABCD}$ \\
\hline T26-1307 & PINMpNPR1 & 95.4 & $\mathrm{ABCD}$ \\
\hline M.26 & & 92.7 & $\mathrm{ABCDE}$ \\
\hline T26-1292 & PINMpNPR1 & 91.8 & $\mathrm{ABCDE}$ \\
\hline T26-1466 & 35SAtNPR1 & 90.4 & ABCDEF \\
\hline T26-1299 & PINMpNPR1 & 90.2 & ABCDEF \\
\hline T26-1302 & PINMpNPR1 & 88.8 & ABCDEFG \\
\hline T26-1287 & PINMpNPR1 & 86.8 & ABCDEFGH \\
\hline T26-1305 & PINMpNPR1 & 84.4 & ABCDEFGHI \\
\hline T26-1301 & PINMpNPR1 & 81.8 & BCDEFGHIJ \\
\hline T26-1308 & PINMpNPR1 & 81.4 & CDEFGHIJ \\
\hline T26-1290 & PINMpNPR1 & 79.4 & CDEFGHIJK \\
\hline T26-1291 & PINMpNPR1 & 78.7 & DEFGHIJKL \\
\hline T26-1288 & PINMpNPR1 & 78.3 & DEFGHIJKL \\
\hline T26-1501 & 35SMpNPR1 & 75.0 & EFGHIKLM \\
\hline T26-1505 & 35SAtNPR 1 & 73.6 & FGHIJKLM \\
\hline T26-1325 & PINMpNPR1 & 71.5 & GHIJKLMN \\
\hline T26-1303 & PINMpNPR1 & 70.9 & GHIJKLMNO \\
\hline T26-1479 & 35SAtNPR1 & 70.8 & GHIJKLMNO \\
\hline T26-1300 & PINMpNPR1 & 69.7 & HIJKLMNO \\
\hline T26-1457 & 35SAtNPR 1 & 67.4 & IJKLMNOP \\
\hline T26-1324 & PINMpNPR1 & 64.2 & JKLMNOPQ \\
\hline T26-1470 & 35SAtNPR1 & 62.0 & KLMNOPQ \\
\hline T26-1480 & 35SAtNPR1 & 61.8 & KLMNOPQ \\
\hline T26-1462 & 35SAtNPR1 & 60.9 & LMNOPQR \\
\hline T26-1528 & 35SMpNPR1 & 60.9 & LMNOPQR \\
\hline T26-1460 & 35SAtNPR 1 & 60.8 & LMNOPQR \\
\hline T26-1468 & 35SAtNPR 1 & 59.4 & MNOPQRS \\
\hline T26-1456 & 35SAtNPR1 & 57.2 & MNOPQRS \\
\hline T26-1298 & PINMpNPR1 & 57.0 & MNOPQRS \\
\hline T26-1461 & 35SAtNPR1 & 54.8 & NOPQRS \\
\hline T26-1459 & 35SAtNPR1 & 54.1 & NOPQRS \\
\hline T26-1506 & 35SAtNPR 1 & 53.5 & NOPQRS \\
\hline T26-1326 & PINMpNPR1 & 53.0 & OPQRS \\
\hline T26-1467 & 35SAtNPR1 & 510 & PQRS \\
\hline T26-1463 & 35SAtNPR1 & 50.4 & PQRS \\
\hline T26-1478 & 35SAtNPR1 & 49.2 & QRST \\
\hline T26-1481 & 35SAtNPR1 & 48.8 & QRST \\
\hline T26-1458 & 35SAtNPR 1 & 47.9 & QRST \\
\hline T26-1528 & 35SMpNPR1 & 47.8 & QRST \\
\hline T26-1502 & 35SMpNPR1 & 43.4 & RST \\
\hline T26-1464 & 35SAtNPR1 & 41.9 & STU \\
\hline T26-1471 & 35SMpNPR1 & 31.2 & TUV \\
\hline T26-1469 & 35SAtNPR1 & 25.1 & UV \\
\hline M.7 & 19.2 & $\mathrm{~V}$ & \\
\hline
\end{tabular}

${ }^{\text {a }}$ Evaluation of fire blight resistance in our own rooted plants containing PINMpNPR1, 35SAtNPR1, and 35SMpNPR1 by shoot inoculation with Erwinia amylovora $\mathrm{Ea} 273$ at $5 \times 10^{6} \mathrm{CFU} \mathrm{ml}^{-1}$ in a growth chamber. trol of the CaMV35S or Pin2 promoter showed a reduction in susceptibility to E. amylovora. Two of these lines (TGx-1520 and TGx-1523) were numerically more resistant than the resistant control M.7. When we observed the responses of the transformed M.26 lines with the same expression constructs (Table 2), a different pattern appeared. Most of the PIN2MpNPR1 M.26 lines did not show a significant increase in resistance; only six of 20 lines tested showed an intermediate level of resistance compared with the nontransformed control M.26. In contrast, when the Malus $\times$ domestica or A. thaliana NPR1 gene was placed under the control of the strong CaMV35S promoter, all transformed M.26 lines showed significantly increased resistance (Table 2). However, only six of 20 PINMpNPR1 M.26 lines, in which the MpNPR1 gene is expressed from the wound-inducible Pin2 promoter, showed an intermediate level of resistance compared with the nontransformed control M.26 (Table 2). Thus, the cultivar backgrounds have an effect on NPRI overexpression-mediated resistance to fire blight (Table 3). In M.26, the MpNPRl gene gave the higher level of increased resistance to E. amylovora when it was under the control of the constitutive $35 \mathrm{~S}$ promoter and a lower increase in resistance when it was under the control of the wound-inducible Pin 2 promoter. Expression of the AtNPRI gene gave an intermediate level of resistance to fire blight. In the cultivar Galaxy, the difference in effect of the three constructs was not obvious. In contrast to what was observed in M.26, a higher level of resistance was observed in Galaxy when the MPNPR1 was under the control of the Pin2 promoter.

Table 3. The overall effectiveness of three expression constructs on fire blight resistance ${ }^{\mathrm{a}}$

\begin{tabular}{lcc}
\hline Constructs or controls & Shoot length infected $(\%)$ & Waller group \\
\hline M.26 & & \\
M.26 (susceptible) & 92.7 & $\mathrm{~A}$ \\
PINMpNPR1 & 78.9 & $\mathrm{~B}$ \\
35SAtNPR1 & 56.7 & $\mathrm{C}$ \\
35SMpNPR1 & 47.4 & $\mathrm{D}$ \\
M.7 (resistant) & 19.2 & $\mathrm{E}$ \\
Galaxy & & \\
M.26 (susceptible) & 83.0 & $\mathrm{~A}$ \\
35SAtNPR1 & 53.3 & $\mathrm{~B}$ \\
35SMpNPR1 & 50.2 & $\mathrm{~B}$ \\
PINMpNPR1 & 39.9 & $\mathrm{C}$ \\
M.7 (resistant) & 22.3 & $\mathrm{D}$ \\
\hline
\end{tabular}

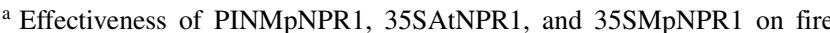
blight resistance of our own rooted Galaxy plants and M.26-transformed plants following shoot inoculation with Erwinia amylovora in a growth chamber. The data from all the transformed lines expressing a given construct were used to calculate the overall effectiveness of the construct.

Table 4. Resistance to Venturia inaequalis (apple scab) ${ }^{\mathrm{a}}$

\begin{tabular}{lcc}
\hline Transformed lines & Infection rating $^{\mathbf{b}}$ & No. of leaves with sporulation \\
\hline Galaxy & 2.48 & $4.86 \pm 0.5$ \\
TGx-1319 & 1.12 & $2.95 \pm 0.3$ \\
TGx-1320 & 1.35 & $3.02 \pm 0.4$ \\
TGx-1323 & 1.01 & $2.62 \pm 0.2$ \\
TGx1509 & 1.09 & $2.83 \pm 0.3$ \\
TGx-1520 & 0.91 & $2.63 \pm 0.3$ \\
TGx-1521 & 0.71 & $2.45 \pm 0.2$ \\
TGx-1523 & 0.77 & $2.50 \pm 0.5$ \\
TGx-1524 & 0.85 & $3.00 \pm 0.2$
\end{tabular}

${ }^{\text {a }}$ Resistance to Venturia inaequalis (apple scab) of our own rooted transformed Galaxy lines containing PINMpNPR1 and 35SMpNPR1 in a growth chamber. Three leaves were inoculated.

b Symptom and infection severity scale: $0=<5 \%$ leaf surface with sporulation, $1=5$ to $25 \%$ leaf surface with sporulation, $2=25$ to $50 \%$ leaf surface with sporulation, and $3=>50 \%$ leaf surface with sporulation. 
We further analyzed the transformed apple plants in the greenhouse. Selected transformed Galaxy lines were grafted onto seedling rootstocks and were inoculated with $E$. amylovora $\mathrm{Ea} 273$ at $5 \times 10^{7} \mathrm{CFU} \mathrm{ml}^{-1}$. Three weeks after inoculation, $78.9 \%$ of the shoot length of nontransformed Galaxy showed necrosis, whereas $17 \%$ of the shoot lengths infected in M.7 (resistant control) were necrotic (Table 1). By contrast, all the transformed Galaxy lines expressing the Malus $\times$ domestica or A. thaliana NPRI gene, under the control of the
CaMV35S or Pin2 promoter, showed a reduction in susceptibility to E. amylovora, which was similar to the reduction of susceptibility observed in the growth chamber.

\section{Resistance to Venturia inaequalis} and Gymnosporangium juniperi-virginianae.

In order to evaluate the range of protection offered by overexpression of the NPRI genes, we examined selected transformed Galaxy lines for resistance to two major fungal
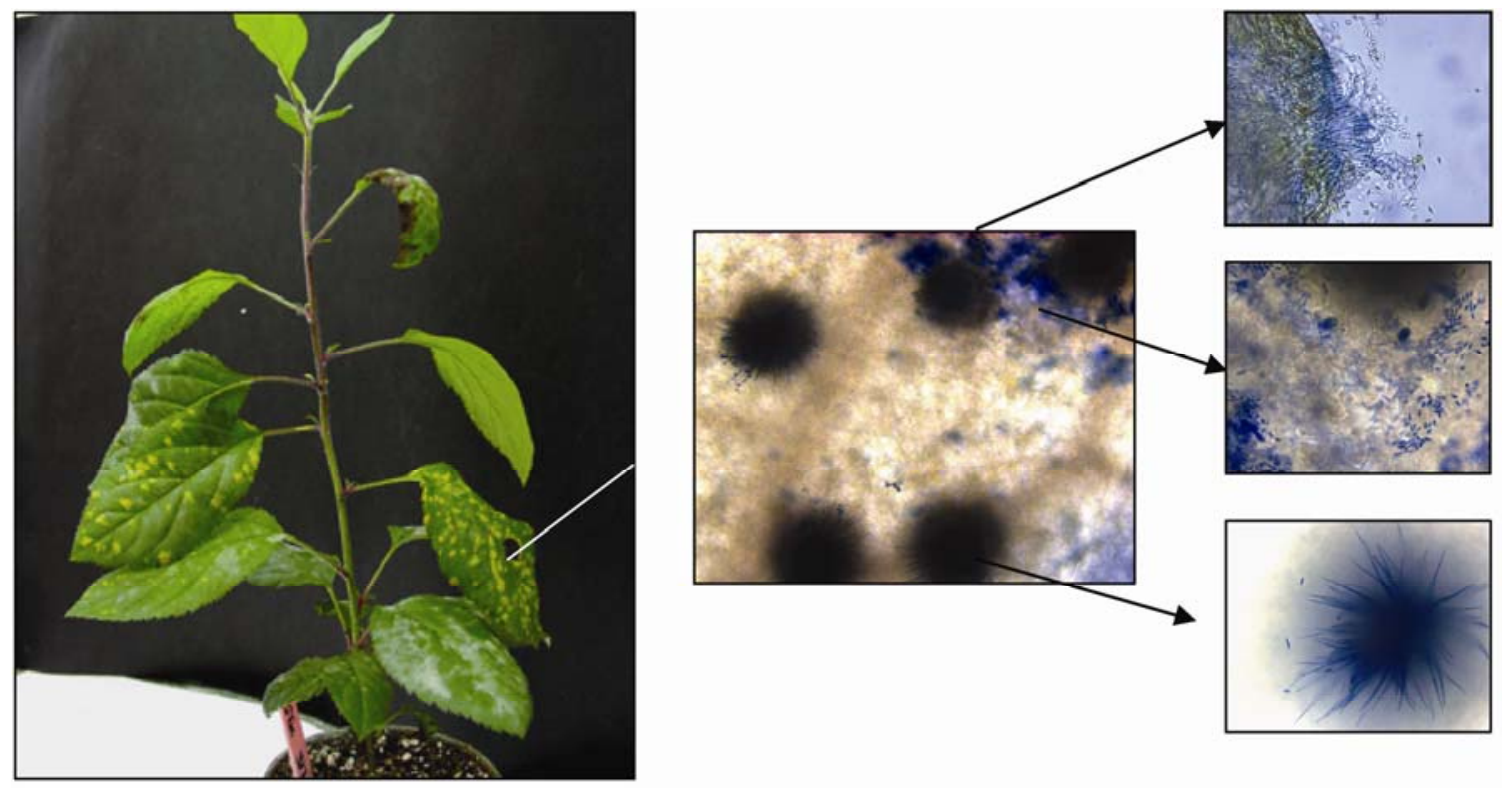

\section{Galaxy}

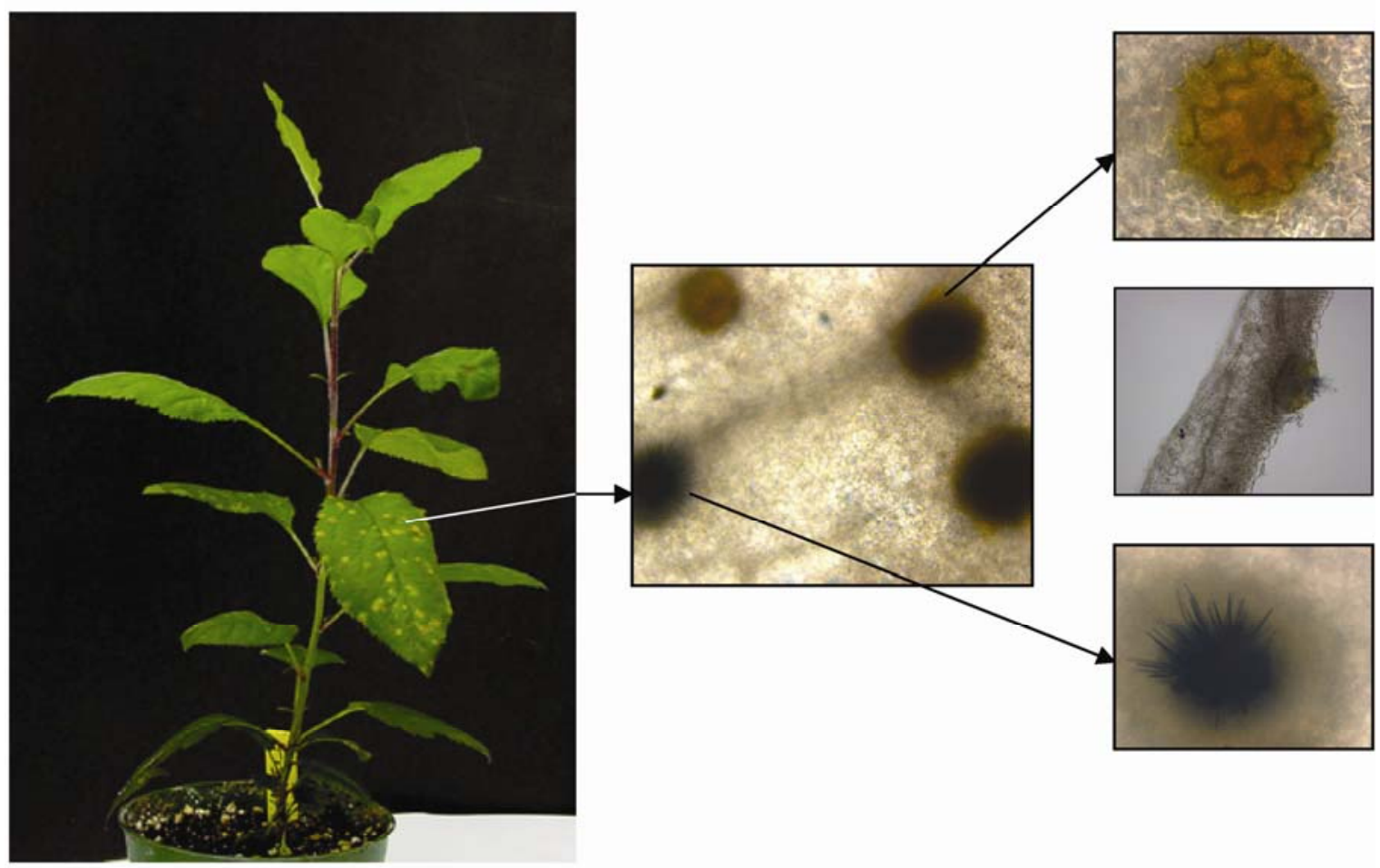

TGX-1319

Fig. 4. Microscopic analysis of MpNPR1 transformed Galaxy apple line TGx-1319 and nontransformed control Galaxy 3 weeks after inoculation with Gymnosporangium juniperi-virginianae. 
pathogens ( $V$. inaequalis and $G$. juniperi-virginianae) of apple.

After $V$. inaequalis inoculation on plants growing in the growth chamber, macroscopic symptoms were evaluated 21 days later and the percentage of leaves with sporulation was determined. Interestingly, there was a reduction of symptoms on leaf surfaces as well as a reduction in the number of leaves infected compared with the Galaxy control (Table 4).

Inoculation with $G$. juniperi-virginianae caused the formation of lesions on the leaf surface. One month after inoculation, a mean of more than 66 lesions could be counted on leaf surfaces of the nontransformed control. The transformed lines tested (TGx-1319, 1320, 1322, 1323, and 1509) showed a reduction of $40 \%$ in the number of necrotic lesions on the adaxial surface of the leaves and a reduction in formation of aecia on the abaxial surfaces (data not shown). After staining of 3-week-old leaves infected with $G$. juniperi-virginianae, microscopic analysis revealed that most of the lesions observed on the transformed lines had necrosis or mycelia without sporulation
(Fig. 4), compared with the nontransformed lines of Galaxy, in which all lesions had mycelial growth with abundant sporulation (Fig. 4).

\section{Molecular characterization of NPR1 gene expression in transformed lines.}

NPR 1 mRNA and protein levels were determined in transformed lines grown in the greenhouse compared with those in nontransformed Galaxy and M.26 plants under the same conditions. As expected, different transformed lines displayed different levels of NPRI mRNA, as revealed by reverse transcriptase (RT)-PCR (Fig. 5), while a faint NPRl mRNA signal was detected in the nontransformed control Galaxy (Fig. 5) and M.26 (data not shown). Overexpression of the NPR1 protein in the transformed lines was also confirmed in all the transformed lines by Western blot for the Galaxy transformed lines expressing the MPMPRI gene under the control of the Pin2 promoter (Fig. 6). Similar results were obtained for the transformed M.26 and Galaxy lines expressing the MpNPRl or

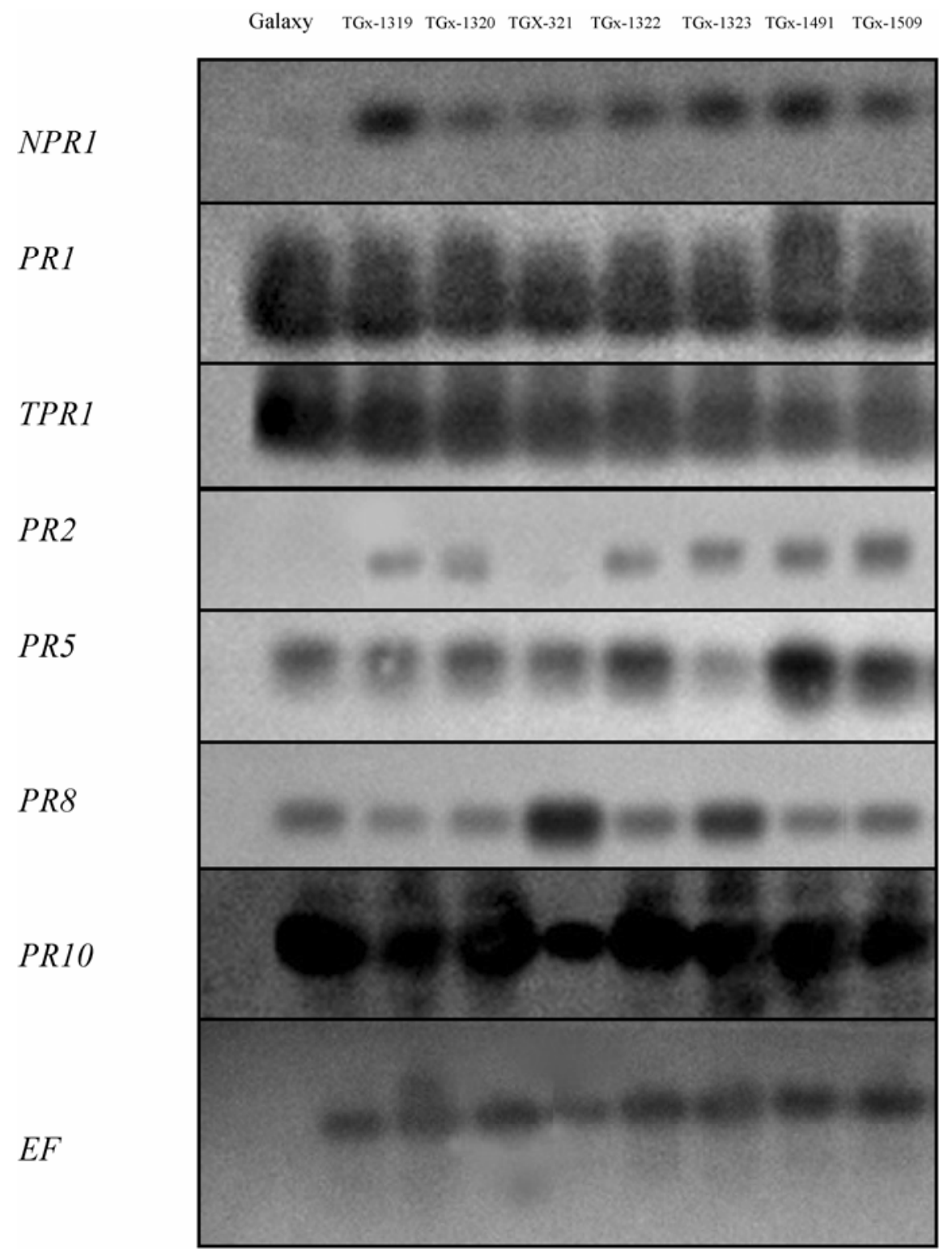

Fig. 5. Comparative reverse transcriptase-polymerase chain reaction (PCR) analysis of $N P R 1, P R 1, T P R 1, P R 2, P R 5, P R 8, P R 10$, and $E F-1 \alpha$ in leaves of acclimated plants from nontransformed Galaxy and transformed lines expressing the MpNPR1 gene under the control of the Pin2 promoter. Differences among transcription levels of transformed plants were estimated after 20 cycles of PCR. The $E F-1 \alpha$ transcript was used as an internal control. Experiments were repeated at least twice with similar results. Results are from one of these experiments. 
AtNPR1 gene under the control of the CaMV35S or Pin2 promoter (data not shown).

Abundance of NPRI transcripts, evaluated by the ratio of RT-PCR signal intensity between NPRI and the control EF1$\alpha$, was correlated in Galaxy with the level of resistance in the growth chamber $(R=0.60, P<0.01$ and $R=0.75, P<0.01$ for the PINMpNPR1 and 35SMpNPR1 constructs, respectively). In M.26, a similar correlation was observed.

We used the Pin 2 promoter, in addition to the CaMV 35S promoter, because it was shown to be inducible by E. amylovora infection. We were, therefore, interested in examining the effect of E. amylovora infection on the expression of the $M p N P R 1$ gene under the control of the Pin2 promoter. Interestingly, before inoculation, the MpNPRI transcript levels were already higher in all transformed lines, as compared with the Galaxy control (Fig. 7). After inoculation with $E$. amylovora, the abundance of NPR 1 transcripts increased rapidly in the transformed lines compared with that in the Galaxy control. This activation of transcription was specific to E. amylovora inoculation, because after inoculation with water the abundance of NPRl transcripts increased only slowly (Fig. 7).

\section{Molecular characterization of $P R$ gene expression in the NPR1-transformed lines.}

We examined whether overexpression of the NPRl gene in apple enhanced the expression of $P R$ genes. Specifically, we checked the expression over time of $P R 1, P R 2, P R 5, P R 8$, and $P R 10$ in selected transformed Galaxy Pin2MpNPR1 lines after inoculation with $E$. amylovora or water. We found that, after inoculation with E. amylovora, the expression of these $P R$ genes, except $P R 10$, was greater in transformed plants than in the Galaxy control inoculated with E. amylovora or in the same transformed lines inoculated with water. The transcript levels of these different $P R$ genes reached maximum levels 48 $\mathrm{h}$ after inoculation (Fig. 8), which was $24 \mathrm{~h}$ after the NPRl gene had reached its maximum expression (Fig. 7).

\section{DISCUSSION}

Genetic engineering of disease resistance through transfer of plant defense-related genes or pathogen-originated genes into crops is valuable in terms of cost, efficacy, and reduction of pesticide usage (Rommens and Kishore 2000; Salmeron and Vernooij 1998; Shah 1997; Stuiver and Custers 2001). Among the strategies used for the genetic engineering of disease resistance, the employment of SAR is of special interest. SAR is long-lasting and appears to be effective against a broad spectrum of pathogens (Durrant and Dong 2004; Ryals et al. 1996). By screening an apple cDNA library with an AtNPR1 probe, we cloned three apple NPRl-like genes, which showed $35 \%$ identity with AtNPR1 at the amino-acid level. Only one of these genes (MpNPR1-1) was found to be induced by the SAR inducer BTH. MPNPRI-1 is, therefore, the most likely candidate for being the ortholog of the Arabidopsis NPRl gene. $M p N P R 1-1$ has no obvious biochemical functions, except for the presence of two protein-interacting domains (the $\mathrm{BTB} / \mathrm{BOZ}$ and ankyrin repeat domains), suggesting that its function is through interaction with other proteins, as has been previously described in A. thaliana (Després et al. 2000; Kim and Delaney 2002; Subramaniam et al. 2001; Zhang et al. 1999, 2006; Zhou et al. 2000). AtNPR1 is located in the cytoplasm as an oligomer under noninducing conditions, and Cys216 is one of the cysteines that are required for keeping AtNPR1 in the cytoplasm (Mou et al. 2003). Sequence comparisons between the three apple NPR1-like proteins indicate that residues near this cysteine are conserved in MpNPR1-1 but not conserved in the MpNPR1-2 and MpNPR1-3 proteins, suggesting that MpNPR1-2 and MpNPR1-3 may have distinct functions.

Our results showed that overexpression of the MpNPRl gene increased the resistance of apple to three important pathogens, fire blight bacterium, apple scab fungus, and cedar apple rust fungus. The broad-spectrum resistance to both bacterial and fungal diseases observed is consistent with previous reports in Arabidopsis, rice, and wheat (Cao et al. 1998; Chern et al. 2001, 2005; Fitzgerald et al. 2004; Friedrich et al. 2001; Lin et al. 2004; Makandar et al. 2006). The fact that overexpression of NPR1 proteins causes similar effects in different plants suggests the presence of similar defense pathways in apple, Arabidopsis, rice, and wheat. It is important to note, however, that there are differences between these different species with regard to their response to the elevated levels of NPR1 gene expression. Although transformed Arabidopsis plants overexpressing AtNPR1 acquire enhanced sensitivity to SA and BTH (Friedrich et al. 2001), they display no obvious

\section{Galaxy $\quad$ M $1319 \quad 13211322 \quad 1323 \quad 14911509$}

\section{Molecular marker $\mathrm{kDa}$}

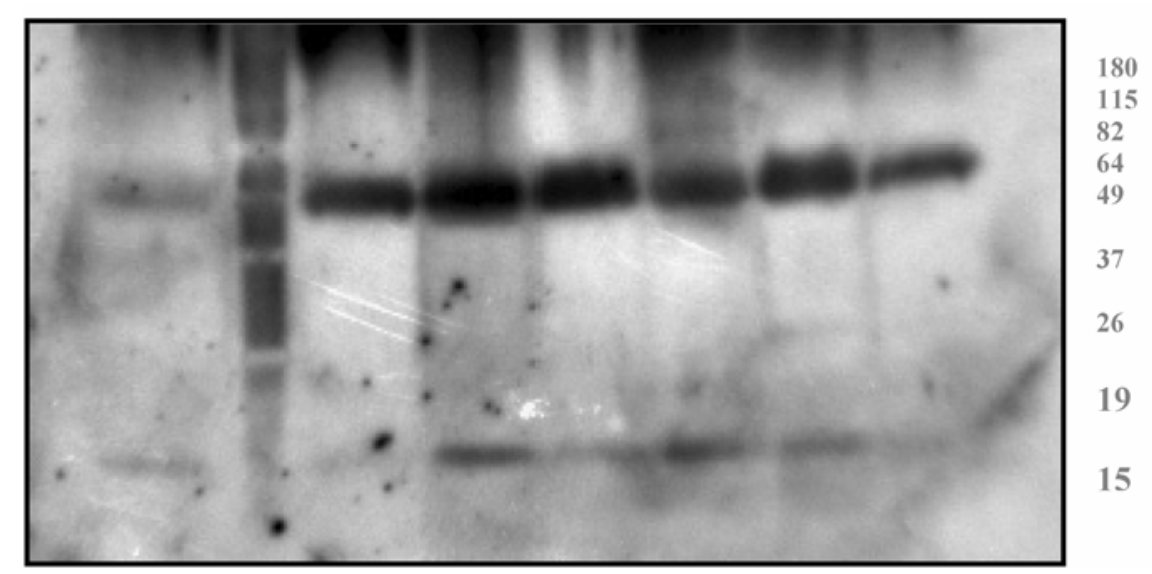

Fig. 6. Western blot analysis of MpNPR1 expression in greenhouse leaves of nontransformed Galaxy plants and MpNPR1-transformed Galaxy lines. Leaf crude extract $(10 \mu \mathrm{g})$ was used for each sample. $\mathrm{M}=$ molecular marker (BenchMark prestained protein ladder, Invitrogen, Carlsbad, CA, U.S.A.). 
detrimental morphological changes and, mostly, do not have elevated $P R$ gene expression until activated by an inducer or by infection (Cao et al. 1998; Friedrich et al. 2001). However, overexpression of $\mathrm{NH} 1$ (rice homolog of AtNPR1) in rice leads to constitutive activation of defense genes and causes a developmentally controlled lesion-mimic phenotype (Chern et al. 2005). In addition, overexpression of either AtNPR1 or $\mathrm{NH} 1$ in rice potentiates a lesion mimic and cell death phenotype that can be triggered by BTH treatment or low light intensity (Fitzgerald et al. 2004). In apple, the overexpression of AtNPR1 or MpNPR1 does not create detrimental morphological changes in our experimental conditions.

Overexpression of the NPRl genes in Arabidopsis, tomato, and rice leads to enhanced nonspecific disease resistance in a dosage-dependent fashion (Cao et al. 1998; Chern et al 2001; Lin et al. 2004). Consistent with these observations, transformed Galaxy lines that accumulated higher levels of NPR1 mRNA and protein exhibited broad-spectrum resistance to several important and different pathogens tested (fire blight, apple scab, and cedar apple rust). It will be of interest to determine in the future whether these transformed plants have enhanced resistance to all major apple diseases. The expression pattern of the $P R$ genes in our Galaxy transformed lines was generally consistent with some of the studies previously reported. In transformed Arabidopsis plants overexpressing AtNPRl, PR gene expression was induced in an AtNPR1-dosage dependent manner (Cao et al. 1998). In this study, expression of some $P R$ genes (e.g., $P R 2, P R 5$, and $P R 8$ ) was enhanced in some of our transformed apple lines; however, the degree of induced $P R$ gene expression did not always correlate with the levels of NPR1 expression, except for the $P R 2$ gene. Our results are similar to what Lin and associates (2004) observed in tomato. Previously, it had been shown that $P R$ gene expression could be either NPR1-dependent or -independent (Zhang and Shapiro 2002) and be uncoupled from bacterial and viral resistance (Clarke et al. 1998). Therefore, the enhanced broadrange disease resistance observed in transformed apple lines may involve the activation of PR2 and some other defenses that were not analyzed in this study. In fact, a major challenge in the field is to elucidate what exact end compounds or cell
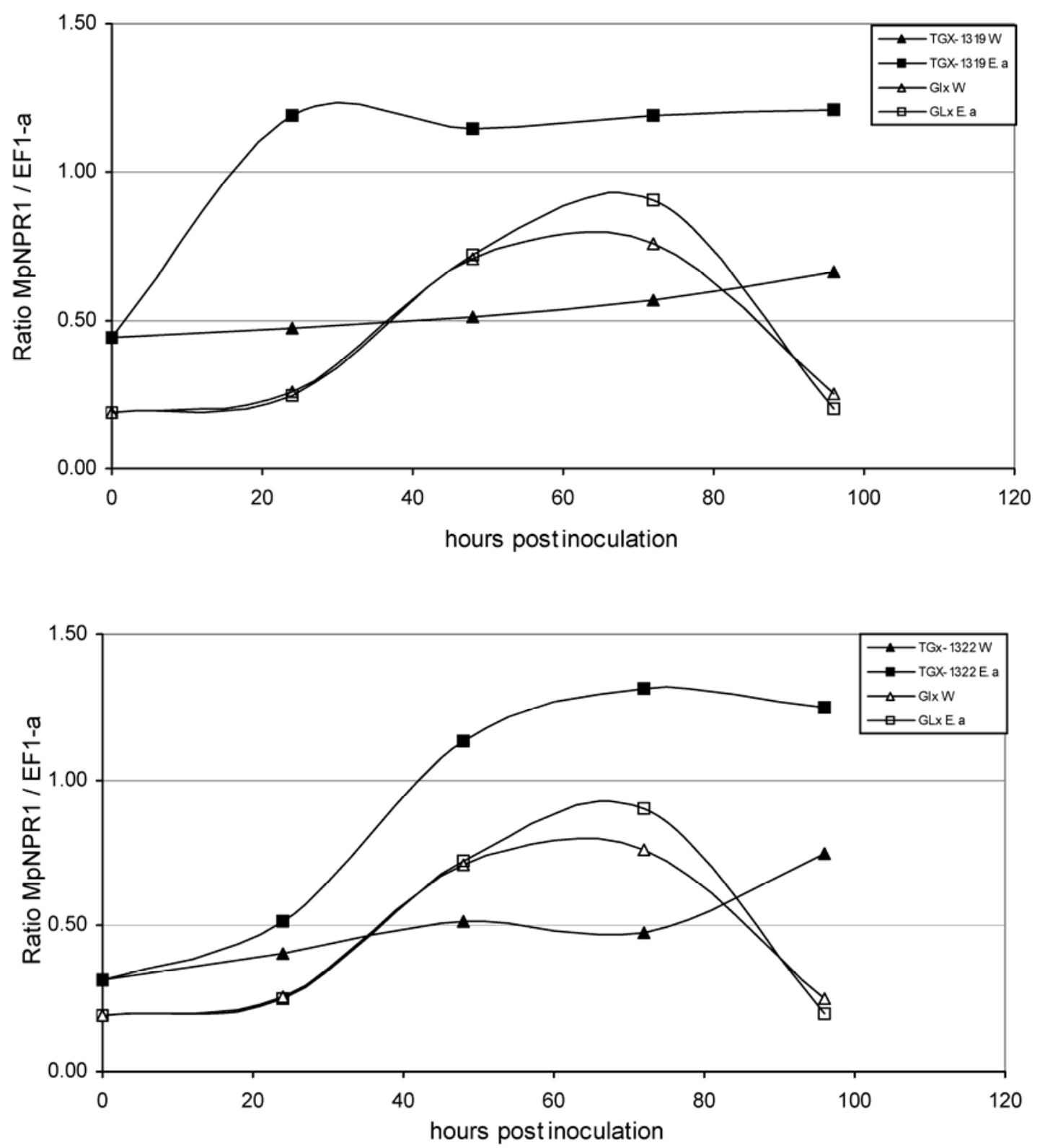

Fig. 7. NPR1 transcript levels in MpNPR1. Top, Galaxy-transformed lines TGx-1319 and bottom, TGx-1322 compared with those in the control Galaxy after inoculation with water (W) or Erwinia amylovora (E.a) at $10^{8} \mathrm{CFU} . \mathrm{ml}^{-1}$. 

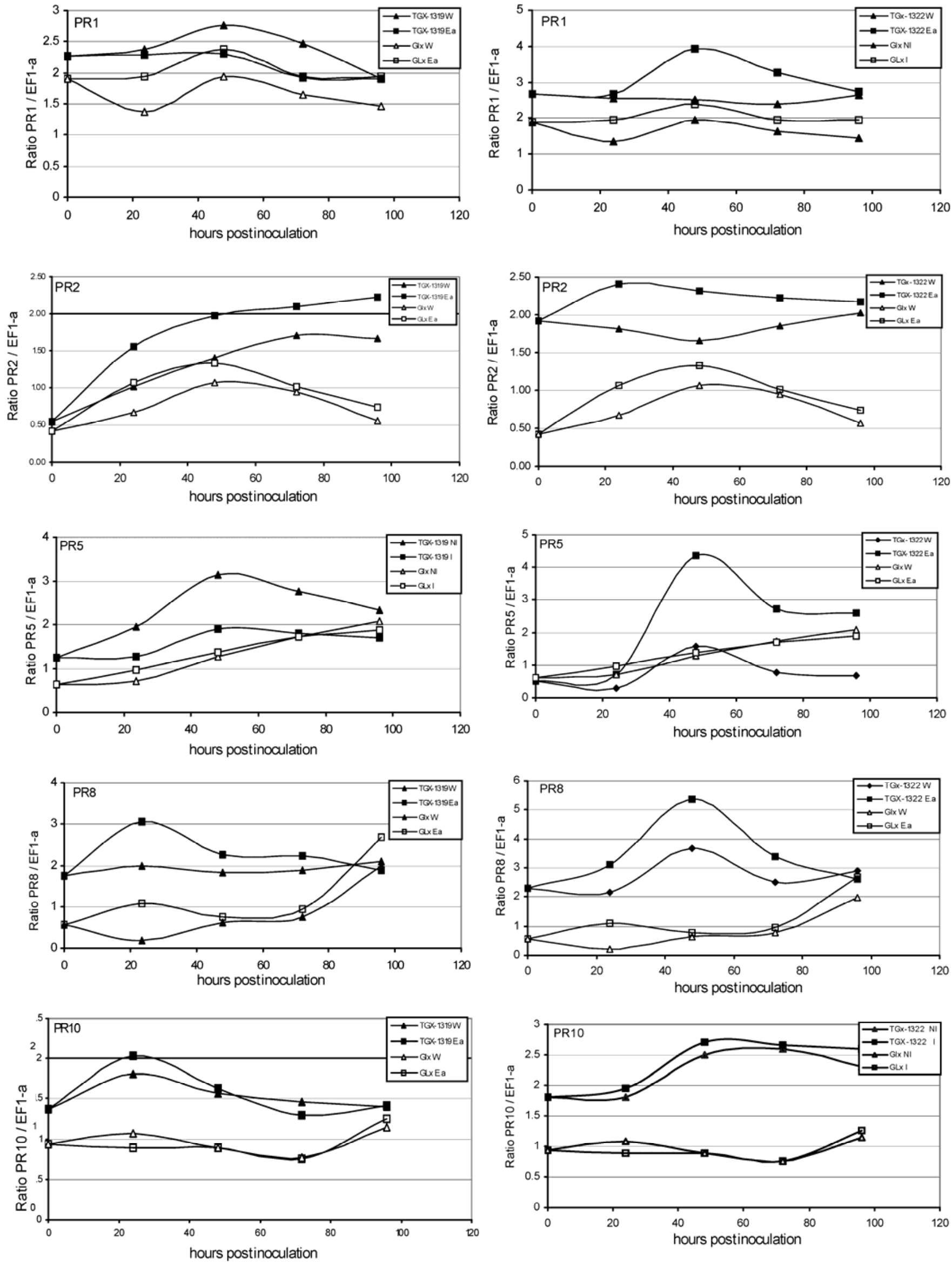

Fig. 8. Pathogenesis-related (PR) transcript levels in MpNPR1-transformed Galaxy lines TGx-1319 and TGx-1322 compared with nontransformed Galaxy after inoculation with water (W) or Erwinia amylovora (E.a) at $10^{8} \mathrm{CFU} . \mathrm{ml}^{-1}$. 
structural modifications, or both, plants use to achieve the resistance state.

\section{MATERIALS AND METHODS}

\section{Cloning of the MpNPR1 gene.}

Green Jonathan apple leaves, sprayed with $0.3 \%$ BTH (wt/vol, commercially available BTH formula dissolved in distilled water) 5 days prior to collection for two consecutive days, were collected from the Michigan State University (East Lansing, MI, U.S.A.) educational apple orchard in the summer of 1998. Total RNA was extracted from these leaves and was used to construct the apple cDNA library in ZAP express vector (Stratagene, La Jolla, CA, U.S.A.). The cDNA library was screened by using the AtNPRl gene as a probe, following the manual provided by Stratagene. cDNA inserts present in all positive isolates were characterized by sequencing and were blasted against AtNPRl gene.

\section{BTH treatment on apple seedlings for Northern blot analysis.}

Apple seedlings were grown to the four-true-leaf stage in a controlled-environment chamber. Leaves were liberally sprayed with BTH $(0.3 \%)$ until completely wet. Five days after treatment, leaves were harvested for isolation of RNA, which was subjected to Northern analysis as indicated elsewhere (Sambrook and Russell 2001).

\section{Bacterial inocula.}

Erwinia amylovora (fire blight). The wild-type strain of $E$. amylovora (Ea 273) was grown overnight at $28^{\circ} \mathrm{C}$ on Kado medium. Inoculum was prepared by suspension of strain Ea273 in distilled water at a concentration of $5 \times 10^{6}$ or $5 \times$ $10^{7} \mathrm{CFU} \mathrm{ml}{ }^{-1}$.

Venturia inaequalis (apple scab). A mixed inoculum of $\mathrm{V}$. inaequalis isolates 1805-2, 1777-8, 1771-2, 1778-6, and 1810-1, representing the five races, race 1 through race 5, was used. Inocula were prepared by suspension of the conidia in distilled water at a concentration of $2.7 \times 10^{7}$ conidia $\mathrm{ml}^{-1}$.

Gymnosporangium juniperi-virginianae (cedar apple rust). Inocula were prepared by suspension of the G. juniperi-virginianae basidiospores in distilled water at a concentration of $2.7 \times 10^{7}$ spores $\mathrm{ml}^{-1}$.

\section{Plasmid constructions.}

Both AtNPRI and MpNPRI-1 genes were amplified and inserted in-frame into pKYLX71 under the control of the CaMV35S promoter or a modified pKYLX71 under the control of the wound-inducible promoter Pin2. Three binary expression vectors, pKYLX35SAtNPR1, pKYLX35SMpNPR1, and pKYLXPINMpNPR1, were finally chosen to be electroporated into super-virulent Agrobacterium tumefaciens EHA105 PCH32 (Hood et al. 1993) for apple transformation.

The primers used for amplifying AtNPR1 and MpNPR1-1 were as follows.

AtNPRl forward:

5'SalI-TCTTCAGTCGACATGGACACCACCA

TTGATGGATTCGCC

AtNPR1 reverse:

5'SacI-GACCATTAGAGCTCACCGACGACGA

TGAGAGAGTTTACG

MpNPR1-1 forward:

5'SalI-TCTTCAGTCGACATGGCTCATTCA

GCCGAACCATCATCC

$M p N P R 1-1$ reverse:

5'SpeI-CCACTAGTCAGTAAACCTCCGAA

GGCTTATTAGATGC
Plant material and transformation.

The apple cultivar Galaxy and the rootstock M.26 were chosen for this study because they can be genetically transformed at high efficiency (Borejsza-Wysocka et al. 1999; Norelli et al. 1999). Leaf segments were excised from in vitro-grown shoots of these two cultivars 3 weeks after subculturing. Transformation experiments were carried out as previously reported (Borejsza-Wysocka et al. 1999; Norelli et al. 1999), using A. tumefaciens EHA105 containing one of the binary vectors pKYLXAtNPR1, pKYLX35SMpNPR1, or pKYLXPINMpNPR1. DNA was isolated from the youngest leaf of putative transformed plants and nontransformed control plants as described by Cheung and associates (1993), and PCR was performed as described by Bolar and associates (1999). In order to check for the presence of promoter-NPRl fusions, specific primers were designed to amplify a fragment of the Pin 2 or $35 \mathrm{~S}$ promoter region and of the $M p N P R l$ or AtNPRl sequence (Table 1). Nontransformed Galaxy, M.26, and transformed clones were propagated in vitro (Norelli et al. 1988). Acclimation of the plants was performed as described by Bolar and associates (1998).

\section{Determination of ploidy level.}

Ploidy level in the transformed and nontransformed clones was estimated by flow cytometry. Nuclei were isolated from in vitro leaves by manually chopping them with a razor blade directly into the buffer described by the manufacturer (Partec, Münster, Germany). After addition of 4,6 diamino-2-phenylindole dihydrochloride (DAPI; $2 \% \mathrm{vol} / \mathrm{vol}$ ) and filtration through a $20-\mu \mathrm{m}$ nylon mesh, the mixture was analyzed with a flow cytometer (Partec II, Partec).

\section{Inoculation procedures.}

Erwinia amylovora. The youngest expanded leaves from our own rooted plants in a growth chamber were inoculated by cutting the leaves transversely with scissors dipped in a suspension $\left(5 \times 10^{6} \mathrm{CFU} \mathrm{ml}^{-1}\right.$ for M.26 or $5 \times 10^{7} \mathrm{CFU} \mathrm{ml}{ }^{-1}$ for Galaxy) of the virulent E. amylovora Ea273.

Venturia inaequalis. The youngest expanded leaf was tagged and the plants were inoculated with a suspension of $V$. inaequalis $\left(2.7 \times 10^{6}\right.$ conidia per milliliter $)$, using an atomizer connected to a compressed air supply (Yepes and Aldwinckle 1993). The plants were incubated in a mist chamber (16-h photoperiod of $40 \mu \mathrm{mol} \mathrm{m} \mathrm{m}^{-2} \mathrm{~s}^{-1}, 18 \pm 1^{\circ} \mathrm{C}$, and $100 \%$ relative humidity) for $48 \mathrm{~h}$ and, later, were moved to a growth chamber. Macroscopic symptoms and infection severity were evaluated

Table 5. Primer sequences used for polymerase chain reaction

\begin{tabular}{|c|c|c|}
\hline Target gene & Primer sequence & $\mathbf{T m}^{\mathbf{a}}{ }^{\circ} \mathbf{C}$ \\
\hline \multirow[t]{2}{*}{ AtNPR1 } & F: ATTGCCGGAAGAGCTTGTTA & 58 \\
\hline & R: AAGACGTTGAGCAAGTGCAA & \\
\hline \multirow[t]{2}{*}{$M p N P R 1$} & $\begin{array}{l}\text { F: TCTTCAGTCGACATGGCTCATTCAGC } \\
\text { CGAACCATCATCC }\end{array}$ & 58 \\
\hline & $\begin{array}{l}\text { R: CCACTAGTCAGTAAACCTCCGAAGG } \\
\text { CTTATTAGATGC }\end{array}$ & \\
\hline \multirow[t]{2}{*}{$T P R 1$} & F: GTAGGCGTTGGTCCCCTTGAC & 55 \\
\hline & R: GATTGCAGTCGCCAACATGT & \\
\hline \multirow[t]{2}{*}{$P R 2$} & F: GGAATTCACTAGTATTCTCGAAG & 58 \\
\hline & R: CAAATAGGTAAGTCTCTGTAGC & \\
\hline \multirow[t]{2}{*}{$P R 3$} & F: GCCGCGAATTCACTAGTG & 54 \\
\hline & R: CCAAACGTAGTCAAATAAGC & \\
\hline \multirow[t]{2}{*}{ PR5 } & F: GAACCAGATGCTCCACGGAC & 54 \\
\hline & R: GGCCGCGAATTCACTAGTGAT & \\
\hline \multirow[t]{2}{*}{ PR8 } & F: GTTAACATAGCCTTCCTC & 54 \\
\hline & R: TGGACATTGAGGGGCTGC & \\
\hline \multirow[t]{2}{*}{ PR10 } & F: TGGGTGTCTACACATTTG & 54 \\
\hline & R: TTAGTTGTATGCGTCGG & \\
\hline
\end{tabular}

${ }^{\mathrm{a}} \mathrm{Tm}=$ temperature of hybridization. 
on all leaves 21 days postinoculation according to the following scale: $0=<5 \%$ of leaf surface with sporulation; $1=5$ to $25 \%, 2=25$ to $50 \%$, and $3=>50 \%$ leaf surface with sporulation. The number of leaves with symptoms was also determined. The median and confidence limits of the three leaves with most infection were calculated to describe the overall response of each line.

Gymnosporangium juniperi-virginianae. The youngest expanded leaf was tagged and the plants were inoculated with a suspension of $G$. juniperi-virginianae $\left(2.7 \times 10^{6}\right.$ conidia $\left.\mathrm{ml}^{-1}\right)$, using an atomizer connected to a compressed air supply (Yepes and Aldwinckle 1993). The plants were incubated in a mist chamber (16-h photoperiod of $40 \mu \mathrm{mol} \mathrm{m} \mathrm{m}^{-2} \mathrm{~s}^{-1}, 18 \pm 1^{\circ} \mathrm{C}$, and $100 \%$ relative humidity) for $48 \mathrm{~h}$ and, later, were moved to a growth chamber. Macroscopic symptoms and infection severity were evaluated on all leaves 21 days postinoculation, by counting the number of lesions.

The presence of $V$. inaequalis conidia and $G$. juniperi-virginianae lesions on the leaf surface of inoculated plants was assessed 3 weeks postinoculation, by optical microscopy. At 21 days postinoculation, leaves were harvested and bleached for $24 \mathrm{~h}$ in a solution of acetic acid/ethanol 100\% (vol/vol). The leaves were transferred into a solution of lactophenol (20 $\mathrm{g}$ of phenol, $6.6 \mathrm{ml}$ of acetic acid, $32.1 \mathrm{ml}$ of glycerol, $20 \mathrm{ml}$ of water) for $24 \mathrm{~h}$, followed by staining for $15 \mathrm{~min}$ with a solution of $0.5 \%$ methylene blue diluted in lactophenol. After washing the leaves with distilled water, the number of conidia and lesions was determined by microscopy.

\section{DNA extraction and detection of T-DNA integration.}

DNA from the transformed lines and nontransformed control were isolated following the procedure of the Nucleon phytopure plant and fungal DNA extraction kits (Amersham, Piscataway, NJ, U.S.A.). HindIII- or EcoRI-digested genomic DNA from a greenhouse-acclimated plant was transferred to Hybond-N nylon membrane. This membrane was hybridized with a fluorescein-labeled probe following the standard procedure of the DIG DNA labeling and detection kit (Roche, Penzberg, Germany).

\section{Semiquantitative reverse transcription-PCR analysis.}

Total RNA (50 to $100 \mu \mathrm{g}$ ) was extracted from $0.5 \mathrm{~g}$ of young leaves excised from in vitro shoots as described by Venisse and associates (2002). Reverse transcription was performed with 2 $\mu \mathrm{g}$ of total RNA. In order to evaluate relative differences in cDNAs between transformed clones, comparative kinetic analysis was conducted by PCR, as suggested by Horikoshi and associates (1992). Initial amounts of PCR substrates were adjusted for each clone on the basis of an equivalent amplification of a cDNA encoding the $\alpha$ subunit of translation elongation factor 1 (EF1- $\alpha)$, a member of a constitutively expressed gene family (Mahe et al. 1992). In order to evaluate differences among clones proportional to differences in initial amounts, we limited the amplification to 20 cycles. PCR of EF1- $\alpha$ was carried out with the specific primers of apple (forward, 5'-ATTGTGGTCATTGGTCATGT-3' and reverse, 5'-CCAATCTTGTAGACATCCTG-3'). In a second step, comparative amplification was carried out with AtNPRI-, MpNPR1-, PR2-, PR5-, PR8-, PR10-, and TPR1-specific primers (Table 5) on equivalent total cDNA. The PCR reaction was run with products from Promega (Madison, WI, U.S.A.). The thermocycler program was $94^{\circ} \mathrm{C}, 5 \mathrm{~min},\left(20\right.$ cycles of $94^{\circ} \mathrm{C}$, $30 \mathrm{~s}$; temperature of hybridization (Table 5), $1 \mathrm{~min} ; 72^{\circ} \mathrm{C}, 1$ min) and $72^{\circ} \mathrm{C}, 15 \mathrm{~min}$ for each amplification. After electrophoresis on $1.2 \%$ agarose gel, amplified products were blotted onto a Hybond-N nylon membrane. This membrane was hybridized with a fluorescein-labeled probe following the standard procedure of Random prime labeling and detection systems (Amersham, Piscataway, NJ, U.S.A.).

\section{Protein extraction and Western blot.}

Protein extraction was carried out from $200 \mathrm{mg}$ of leaves from in vitro shoots for each transformed clone, according to Ko and associates (2002). For Western analysis, $50 \mu \mathrm{g}$ aliquots of protein extracted from control and transformed clones in Laemmli buffer were separated on $16 \%$ sodium dodecyl sulfatetricine polyacrylamide (wt/vol) gel. After electrophoresis, proteins were blotted onto Hybond $\mathrm{C}$ nitrocellulose membrane (Amersham) by passive transfer. Polyclonal rabbit antiMpNPR1 antiserum or anti-AtNPR1 was used. NPR1 proteins were detected with the enhanced chemiluminescence Western blotting detection system (ECL, Amersham) using horseradish peroxidase-labeled secondary antibody, according to the manufacturer's instructions.

\section{ACKNOWLEDGMENTS}

We gratefully acknowledge M. J. Abbot, S. A. Kuehne, and H. L. Gustafson for excellent technical assistance. We are grateful to X. Dong for providing us with AtNPR1 antibody and for useful discussions. The authors thank P. Abbott for excellent critical reading of the manuscript and J. Rodrigues for phylogenetic analysis of apple and Arabidopsis NPR1 homologs. This work was supported by New York apple growers through a grant from the New York Apple Research and Development Program to H. Aldwinckle, a grant from the U.S. Department of Energy Bioscience Program to S. Y. He, and by a special grant from United States Department of Agriculture Cooperative State Research Education and Extension Service to Cornell University and Michigan State University.

\section{LITERATURE CITED}

Aravind, L., and Koonin, E. V. 1999. Fold prediction and evolutionary analysis of the pOZ domain: Structural and evolutionary relationship with the potassium channel tetramerization domain. J. Mol. Biol. 285:1353-1361.

Baldwin, A. S. 1996. The NF-kB abd IkB proteins: New discoveries and insights. Annu. Rev. Immunol. 14:649-683.

Bolar, J. P., Hanke, V., Norelli, J. P., and Aldwinckle, H. S. 1998. An efficient method to root and acclimatize micropropagated apple cultivars. HortScience 33:1251-1252.

Bolar, J. P., Brown, S. K., Norelli, J. P., and Aldwinckle, H. S. 1999. Factors affecting the transformation of Marshall McIntosh apple by Agrobacterium tumefaciens. Plant Cell Tiss. Org. 55:31-38.

Bolar, J. P., Norelli, J. P., Wong, K. W., Hayes, C. K., Harman, G. E., and Aldwinckle, H. S. 2000. Expression of endochitinase from Trichoderma harzianum in transgenic apple increases resistance to scab and reduces vigor. Phytopathology 92:72-77.

Borejsza-Wysocka, E., Norelli, J. L., Ko, K., and Aldwinckle, H. S. 1999. Transformation of authentic M.26 apple rootstock for enhanced resistance to fire blight. Acta Hort. 489:259-266.

Cao, H., Bowling, S. A., Gordon, S. A., and Dong, X. 1994. Characterization of an Arabidopsis mutant that is nonresponsive to inducers of systemic acquired resistance. Plant Cell 6:1583-1592.

Cao, H., Glazebrook, J., Clarke, J. D., Volko, S., and Dong, X. 1997. The Arabidopsis NPRl gene that controls systemic acquired resistance encodes a novel protein containing ankyrin repeats. Cell 88:57-63.

Cao, H., Li, X., and Dong, X. 1998. Generation of broad-spectrum disease resistance by overexpression of an essential regulatory gene in systemic acquired resistance. Proc. Natl. Acad. Sci. U.S.A. 11:6531-6536.

Chern, M. S., Fitzgerald, H. A., Yadav, R. C., Canlas, P. E., Dong, X., and Ronald, P. C. 2001. Evidence for a disease-resistance pathway in rice similar to the NPR1 mediated signaling pathway in Arabidopsis. Plant J. 27:101-113.

Chern, M., Fitzgerald, H. A., Canlas, P. E., Navarre, D. A., and Ronald, P. C. 2005. Overexpression of a rice NPR1 homolog leads to constitutive activation of defense response and hypersensitivity to light. Mol. PlantMicrobe Interact. 18:511-520.

Cheung, W. Y., Hubert, N., and Landry, B. S. 1993. A simple and rapid DNA microextraction method for plant, animal, and insect suitable for RAPD and other PCR analyses. PCR Meth. Appl. 3:31-40.

Chisholm, S. T., Coaker, G., Day, B., and Staskawics, B. J. 2006. Host-microbe interactions: Shaping the evolution of the plant immune response. 
Cell 124:803-814.

Clarke, J. D., Liu, Y., Klessig, D. F., and Dong, X. 1998. Uncoupling PR gene expression from NPR1 and bacterial resistance: Characterization of the dominant Arabidopsis cpr6-1 mutant. Plant Cell 10:557-569.

Delaney, T. P., Friedrich, L., and Ryals, J. A. 1995. Arabidopsis signal transduction mutant defective in chemically and biologically induced disease resistance. Proc. Natl. Acad. Sci. U.S.A. 92:6601-6606

Dempsey, D. A. Shah, J., and Klessig, D. F. 1999. Salicylic acid and disease resistance in plants. Crit. Rev. Plant Sci. 18:547-575.

Després, C., Delong, C., Glaze, S., Liu, E., and Forbert, P. R. 2000. The Arabidopsis NPR1/NIM1 protein enhances the DNA binding activity of a subgroup of the TGA family of bZIP transcription factors. Plant Cell 12:279-290.

Durrant, W. E., and Dong, X. 2004. Systemic acquired resistance. Annual Rev. Phytopathol. 42:185-209.

Faize, M., Malnoy, M., Dupuis, F., Chevalier, M., Parisi, L., and Chevreau, E., 2003. Chitinase of Trichoderma atroviride induces scab resistance and metabolic changes in two cultivars of apple. Phytopathology 93:1496-1504.

Faize, M., Sourice, S., Dupuis, F., Parisi, L., Gautier, M. F., and Chevreau, E. 2004. Expression of wheat puroindoline-b reduces scab susceptibility in transgenic apple (Malus $\times$ domestica Borkh.). Plant Science 16:347-354.

Fan, W., and Dong, X. 2002. In vivo interaction between NPR1 and transcription factor TGA2 leads to salicylic acid-mediated gene activation in Arabidopsis. Plant Cell 14:1377-1389.

Fitzgerald, H. A., Chern, M.-S., Navarre, R., and Ronald, P. C. 2004 Overexpression of (At)NPR1 in rice leads to a BTH and environment induced lesion mimic/cell death phenotype. Mol. Plant-Microbe Interact. 17:140-151.

Friedrich, L., Lawton, K., Dietrich, R., Willits, M., Cade, R., and Ryals, J. 2001. NIM1 overexpression in Arabidopsis potentiates plant disease resistance and results in enhanced effectiveness of fungicides. Mol. PlantMicrobe Interact. 14:1114-1124.

Gaffney, T., Friedrich, L., Vernooij, B., Negretto, D., Nye, G., Ukness, S. Ward, E. Kessmann, H., and Ryals, J. 1993. Requirement of salicylic acid for the induction of systemic acquired resistance. Science 261:754756

Gorlach, J., Volrath, S., Knauf-Beiter, G., Hengy, G., Beckhove, U., Kogel, K. H., Oostendorp, M., Staub, T., Ward, E., Kessmann, H., and Ryals, J. 1996. Benzothiadiazole, a novel class of inducers of systemic acquired resistance, activates gene expression and disease resistance in wheat. Plant Cell 4:629-643.

Greengerq, J. T., and Yao, N. 2004. The role and regulation of programmed cell death in plant-pathogen interactions. Cell. Microbiol. 6:201-211.

Hammond-Kosack, K. E., and Jones, J. D. G. 1996. Resistance gene dependent plant defense responses. Plant Cell 8:1773-1791.

Horikoshi, T., Danenberg, K. D., Stadlauer, T. H. W., Volkenandt, M., Shea, L. C. C., Aigner, K., Gustavsson, B., Leichman, L., Frösing, R., Ray, M., Gibson, N. W., Spears, C. P., and Danenberg, P. V. 1992. Quantification of thymidylate synthase, dihydrofolate reductase, and DT-diaphorase gene expression in human tumors using the polymerase chain reaction. Cancer Res. 52:108-116.

Kim, H. S., and Delaney, T. P. 2002. Over-expression of TGA5, which encodes a bZIP transcription factor that interacts with NIM1/NPR1, confers SAR-independent resistance in Arabidopsis thaliana to Peronospora parasitica. Plant J. 32:151-163.

Kinkeman, M., Fan, W., and Dong, X. 2000. Nuclear localization of NPR1 is required for activation of PR gene expression. Plant Cell 12:2339 2350 .

Ko, K., Norelli, J. L., Reynoird, J. P., Borejsza-Wysocka, E., Brown, S. K., and Aldwinckle, H. S. 2000. Effect of untranslated leader sequence of AMV RNA 4 and signal peptide of pathogenesis-related protein $1 \mathrm{~b}$ on attacin gene expression, and resistance to fire blight in transgenic apple. Biotechnol. Lett. 22:373-381.

Ko, K., Norelli, J.L., Reynoird, J. P., Aldwinckle, H. S. and Brown, S. K. 2002. T4 lysozyme and attacin genes enhance resistance of transgenic Galaxy apple against Erwinia amylovora. J. Amer. Soc. Hort. Sci. 127:515-519.

Lin, W. C., Lu, C. F., Wu, J. W., Cheng, M. L., Lin, Y. M., Yang, N. S., Black, L., Green, S. K., Wang, J. W., and Cheng, C. P. 2004. Transgenic tomato plants expressing the Arabidopsis NPR1 gene display enhanced resistance to a spectrum of fungal and bacterial diseases. Transgenic Res. 13:567-581.

Mahe, A., Grisvard, J., and Dron, M. 1992. Fungal and specific gene markers to follow the bean-anthracnose infection process and normalize the bean chitinase mRNA induction. Mol. Plant-Microbe Interact. 5:242-248.

Makandar, R., Essig, J. S., Schapaugh, M. A., Trick, H. N., and Shah J. 2006. Genetically engineered resistance to Fusarium head blight in wheat by expression of Arabidopsis NPR1. Mol. Plant-Microbe Interact. 19:123-129.

Métraux, J. P., Signer, H., Ryals, J., Ward, E., Wyss-Benz, M., Gaudin, J., Raschdorf, K., Schmidt, E., Blum, W., and Inveradi, B. 1990. Increase in salicylic acid at the onset of systemic acquired resistance in cucumber. Science 250:1004-1006.

Morris, S. W., Vernooij, B., Titatarn, S., Starret, M., Thomas, S., Wiltse, C. C., Frederiksen, R. A., Bhandhufalck, A., Hubert, S., and Uknes, S. 1998. Induced resistance responses in maize. Mol. Plant-Microbe Interact. 11:643-658.

Morrisey, J. P., and Osbourn, A. E. 1999. Fungal resistance to plant antibiotics as a mechanism of pathogenesis. Microbiol. Mol. Biol. Rev. 63:708-724.

Mou, Z., Fan, W., and Dong, X. 2003. Inducers of plant systemic acquired resistance regulate NPR1 function through redox changes. Cell 113:935-944.

Niggeweg, R., Thurow, C., Kegler, C., and Gatz, C. 2000. Tobacco transcription factor TGA2.2 is the main component of as-1 binding factor ASF-1 and is involved in salicylic acid and auxin inducible expression of as- 1 containing target promoters. J. Biol. Chem. 275:19897-19905.

Norelli, J. L., Mills J. Z. and Aldwinckle H. S. 1988. Leaf wounding increases efficiency of Agrobacterium tumefaciens mediated transformation of apple. HortScience 31:1026-1027.

Norelli, J. L., Mills, J. Z., Momol, M. T., and Aldwinckle, H. S. 1999. Effect of cecropin-like transgenes on fire blight resistance of apple. Acta Hort. 489:273-278.

Pieterse, C. M., van Wees S. C., van Pelt, J. A., Knoester, M., Laan, R., Gerrits, H., Weisbeek, P. J., and van Loon, L. C. 1998. A novel signaling pathway controlling induced resistance in Arabidopsis. Plant Cell 10:1571-1580.

Puite, K. J., and Schaart, J. G. 1996. Genetic modification of the commercial apple cultivars Gala, Golden Delicious and Elstar via an Agrobacterium tumefaciens-mediated transformation method. Plant Sci. 119:125133.

Reynoird, J. P., Mourgues, F., Norelli, J. L., Aldwinckle, H. S., Brisset, M. N., and Chevreau, E. 1999. First evidence for improved resistance to fire blight in transgenic pear expressing the attacin E gene from Hyalophora cecropia. Plant Sci. 149:13-22.

Rommens, C. M., and Kishore, G. M. 2000. Exploiting the full potential of disease-resistance genes for agricultural use. Curr. Opin. Biotechnol. 11:120-125.

Ryals, J. A., Neuenschwander, U. H., Willits, M. G., Molina, A., Steiner, H. Y., and Hunt, M. D. 1996. Systemic acquired resistance. Plant Cell 8:1809-1819

Ryals, J., Weymann, K., Lawton, K., Friedrich, L., Ellis, D., Steiner, H. Y. Johnson, J., Delaney, T. P., Jesse, T., Vos, P., and Uknes, S. 1997. The Arabidopsis NIM1 protein shows homology to the mammalian transcription factor inhibitor I kappa B. Plant Cell 9:425-439.

Salmeron, J. M., and Vernooij, B. 1998. Transgenic approaches to microbial disease resistance in crop plants. Curr. Opin. Plant Biol. 1:347-352.

Sambrook, J., and Russell, D. 2001. Molecular Cloning: A Laboratory Manual, 3rd ed. Cold Spring Harbor Laboratory Press. Cold Spring Harbor, NY, U.S.A.

Scorza, R., Ravelonandro, M., Callahan, A. M., Cordt, J. M., Fuchs, M., Dunez, J., and Gonsalves, D. 1994. Transgenic plums (Prunus domestica L.) express the plum pox virus coat protein gene. Plant Cell Rep 14:18-22.

Shah, D. M. 1997. Genetic engineering for fungal and bacterial disease. Curr. Opin. Biotechnol. 8:208-214.

Shah, J., Tsui, F., and Klessig, D. F. 1997. Characterization of a salicylic acid insensitive mutant (sail) of Arabidopsis thaliana, identified in a selective screen utilizing the SA inducible expression of the tms 2 gene. Mol. Plant-Microbe Interact. 10:69-78.

Somssich, I. E. 2003. Closing another gap in the plant SAR puzzle. Cell 113:815-816.

Spoel, S. H., Koornneef, A., Claessens, S. M., Korzelius, J. P., Van Pelt, J. A., Mueller, M. J., Buchala, A. J., Métraux, J. P., Brown, R., Kazan, K., Van Loon, L. C., Dong, X., and Pieterse, C. M. 2003. NPR1 modulates cross talk between salicylate and jasmonate dependent defense pathway through a novel function in the cytosol. Plant Cell 15:760-770.

Smith, C. J. 1996. Accumulation of phytoalexins: Defense mechanism and stimulus response system; New Phytol. 132:1-45.

Sticher, L., Mauch-Mani, B., and Métraux, J. P. 1997. Systemic acquired resistance. Annu. Rev. Phytopathol. 35:235-270.

Stuiver, M. H., and Custers, J. H. 2001. Engineering disease resistance in plants. Nature 411:865-868.

Subramaniam, R., Desveaux, D., Spickler, C., Michnick, S. W., and Brisson, N. 2001. Direct visualization of protein interactions in plant cells. Nat. Biotechnol. 19:769-772.

Szankowski, I., Briviba, K., Fleschhut, J., Schoenherr, J., Jacobsen, H. J., 
and Kiesecker, H. 2003. Transformation of apple (Malus domestica Borkh.) with the stilbene synthase gene from grapevine (Vitis vinifera L.) and a PGIP gene from kiwi (Actinidia deliciosa). Plant Cell Rep. 22 41-149.

Takken, F. L. W., and Joosten, M. H. A. J. 2000. Plant resistance genes: Their structure , function and evolution. Eur. J. Plant Path. 106:699-713.

Thomson, S. V. 2000. Epidemiology of fire blight. Pages 9-36 in: Fire Blight. J. Vanneste, ed. CAB Int., New York.

Venisse, J.-S., Malnoy, M., Faize, M., Paulin, J.-P., and Brisset, M.-N. 2002. Modulation of defense responses of Malus spp. during compatible and incompatible interactions with Erwinia amylovora. Mol. Plant Microbe Interact. 15:1204-1212.

Yepes, L. M., and Aldwinckle, H. S. 1993. Pathogenesis of Venturia ineaqualis on shoot tip cultures and on greenhouse grown apple cultivars. Phytopathology 83:1155-1162.
Zhang, Y., Fan, W., Kinkema, M., Li, X., and Dong, X. 1999. Interaction of NPR1 with basic leucine zipper protein transcription factors that bind sequences required for salicylic acid induction of the PR-1 gene. Proc. Natl. Acad. Sci. U.S.A. 96:6523-6528.

Zhang, C., and Shapiro, A. D. 2002. Two pathways act in an additive rather than obligatorily synergistic fashion to induce systemic acquired resistance and PR gene expression. BMC Plant Biol. 2:9.

Zhang, Y., Cheng, Y. T., Qu, N., Zhao, Q., Bi, D., and Li, X. 2006. Negative regulation of defense responses in Arabidopsis by two NPR1 paralogs. Plant J. 48:647-656.

Zhou, J.-M., Trifa, Y., Silva, H., Pontier, D., Lam, E., Shah, J., and Klessig, D. F. 2000. NPR1 differentially interacts with members of the TGA/OBF family of transcription factors that bind an element of the $P R-1$ gene required for induction by salicylic acid. Mol. Plant-Microbe Interact. 13:191-202. 